\title{
Learning From Early Attempts to Generalize Darwinian Principles to Social Evolution
}

\author{
Geoffrey M. Hodgson \\ University of Hertfordshire Business School Working Paper 2009 \\ University of Hertfordshire Business School Working Papers are available for \\ download from https://uhra.herts.ac.uk/dspace/handle/2299/619
}

The Working Paper Series is intended for rapid dissemination of research results, workin-progress, and innovative teaching methods, at the pre-publication stage. Comments are welcomed and should be addressed to the individual author(s). It should be remembered that papers in this series are often provisional and comments and/or citations should take account of this.

Copyright and all rights therein are retained by the authors. All persons copying this information are expected to adhere to the terms and conditions invoked by each author's copyright. These works may not be re-posted without the explicit permission of the copyright holders.

The Business School at the University of Hertfordshire (UH) employs approximately 150 academic staff in a state-of-the-art environment located in Hatfield Business Park. It offers 17 undergraduate degree programmes, 21 postgraduate programmes and there are about 80 research students, mostly working at doctoral level.

Business School staff are active in research in numerous areas, including complexity theory, institutional economics, economic modelling, efficiency measurement the creative industries, employment studies, finance, accounting, statistical methods and management science.

The University of Hertfordshire has been recognised as the exemplar of a business-facing university. It is one of the region's largest employers with over 2,700 staff and a turnover of $£ 205 \mathrm{~m}$.

In the 2008 UK Research Assessment Exercise it was given the highest rank for research quality among the post-1992 universities. 


\title{
Learning From Early Attempts to Generalize Darwinian Principles to Social Evolution
}

\author{
Geoffrey M. Hodgson
}

12 September 2009

For Alex Mesoudi and a special issue of the Journal of Evolutionary Psychology

The Business School, University of Hertfordshire, De Havilland Campus, Hatfield, Hertfordshire AL10 9AB, UK www.geoffrey-hodgson.info g.m.hodgson@herts.ac.uk

\begin{abstract}
KEY WORDS:
Social evolution, cultural evolution, generalized Darwinism, replication, institutions, selection, Thorstein Veblen, David Ritchie, Albert Keller
\end{abstract}

\begin{abstract}
Evolutionary psychology places the human psyche in the context of evolution, and addresses the Darwinian processes involved, particularly at the level of genetic evolution. A logically separate and potentially complementary argument is to consider the application of Darwinian principles not only to genes but also to social entities and processes. This idea of extending Darwinian principles was suggested by Darwin himself. Attempts to do this appeared as early as the 1870 s and proliferated until the early twentieth century. But such ideas remained dormant in the social sciences from the 1920s until after the Second World War. Some lessons can be learned from this earlier period, particularly concerning the problem of specifying the social units of selection or replication.
\end{abstract}




\title{
Learning From Early Attempts to Generalize Darwinian Principles to Social Evolution
}

\author{
Geoffrey M. Hodgson
}

Evolutionary psychology upholds that assumptions concerning human mental capacities must be consistent with our understanding of human evolution over the last hundred thousand years or so. ${ }^{1}$ In this period our genetic constitution has changed relatively little (notwithstanding some important genetic changes due to major modifications in diet etc.). Evolutionary psychology addresses the Darwinian processes involved, particularly the longstanding genetic drivers of human mental development.

A logically separate and potentially complementary argument is to consider the application of Darwinian principles to social entities and processes. In other words, we consider how Darwinian principles operate on entities at a higher level, in addition to genes. Such evolution at the social level might occur, even if there was negligible change in the human gene pool. It might thus help to explain the extremely rapid evolution of culture, social institutions and technology over the last few thousand years, in a period when genetic changes have been virtually negligible.

This idea of extending Darwinian principles to social entities was suggested by Darwin $(1859,1871)$ himself. He speculated that his evolutionary principles of variation, inheritance and selection might apply to the evolution of human language, as well as to moral principles in social groups. A sequence of other authors followed suit, but they did not resolve the conceptual problems in defining what exactly we mean by social evolution, as something more than the evolution of a mere collection of human beings. Indeed, an adequate conceptual explanation of the units and processes of Darwinian social evolution has yet to appear, although such an account may now be possible.

\footnotetext{
1 This essay uses material from Hodgson (2004a, 2006).
} 
Section 1 below outlines the basic idea of a generalized (or 'universal') Darwinism. Section 2 outlines a number of early predecessors of the idea, with emphasis on attempts to extend Darwinism to human social evolution. It is shown that these early accounts of social evolution typically focus on the individual, rather than social units of replication or selection. Second 3 focuses more particularly on some early accounts of units of replication or selection in social evolution that emerged from the 1890s. Second 4 concludes the essay, and highlights some implications for recent attempts to extend Darwinism into the social domain.

\section{Generalizing Darwinism}

Richard Dawkins (1983) coined the term 'Universal Darwinism'. Dawkins (1976) also proposed the 'meme' as the unit of cultural replication and selection. He argues that the core Darwinian principles of variation, replication and selection may apply not only to biological phenomena, but to other open and evolving systems, including human cultural or social evolution. ${ }^{2}$ As long as there is a population of varied and imperfectly replicating entities, and not all of these entities have the potential to survive, then Darwinian evolution will occur.

The idea that Darwinism can be applied to other open and evolving systems has been developed by several other contemporary authors, including Richard Lewontin (1970), Friedrich Hayek (1988), David Hull (1988, Hull et al. 2001), Henry Plotkin (1994), Daniel Dennett (1995), Howard Aldrich et al. (2008), and Geoffrey Hodgson and Thorbørn Knudsen (2008b, forthcoming).

Darwinian principles have been applied to the development of neural connections in the brain, the immune system, and computer viruses (Edelman 1987, Plotkin 1994, Aunger 2002). These studies suggest evolutionary processes (additional to those at the genetic level) that involve the core Darwinian principles of variation, inheritance and selection.

Darwinian principles are not tied to the specifics of genes or DNA. Generalizing Darwinism does not amount to a version of biological reductionism where an attempt is made

\footnotetext{
2 Dawkins (1983) shows that even if there were Lamarckian inheritance of acquired characters, a coherent evolutionary account would still require the key principles of Darwinism. Lamarckism and Darwinism are not mutually exclusive (Hodgson and Knudsen 2006b). Darwin (1859) himself believed in the 'Lamarckian' inheritance of acquired biological characters, but now this idea is widely rejected by biologists. Darwinism, in contrast, applies to both biological and social evolution.
} 
to explain everything in biological terms. On the contrary, it upholds that there is a core set of general Darwinian principles that, along with auxiliary explanations specific to each scientific domain, may apply to a wide range of phenomena. Gary Cziko (1995) describes this 'universal selection theory' as 'the Second Darwinian Revolution'. The detailed mechanisms of change at the social level are quite different from those described in biology; but socioeconomic evolution is still Darwinian at this abstract theoretical level.

But a generalized Darwinism itself provides no alternative to a detailed explanation of the particular processes at the social or biological levels. Even in biology, Darwinian principles provide a general explanatory framework into which particular explanations also have to be placed. Generalized Darwinian principles cannot give us a full, detailed explanation of evolutionary processes or outcomes. They provide a meta-theoretical framework rather than a complete theory.

The application of Darwinian principles to socio-economic phenomena depends crucially on the existence of enduring variety, mechanisms of inheritance, and processes of selection. Clearly, the identification of these processes depends decisively on precise definitions of inheritance (or replication) and selection. In addition, the levels of selection have to be made clear, along with the units at each level. Some significant progress has been made in refining these concepts in recent years, while there are still important theoretical, conceptual and definitional issues to resolve. ${ }^{3}$

\section{Early Extensions of Darwinism to Human Social Evolution}

A few years after the publication of his Origin of Species (1859), several scholars followed Darwin's hints that the principles of selection, variation and inheritance may have a wider applicability than to biological organisms alone, including to the evolution of human society.

Walter Bagehot (1872) loosely but explicitly applied the principles of selection and inheritance to ideas and political institutions. William James (1880) considered the natural

\footnotetext{
3 See Price (1995), Sterelny et al. (1996), Sperber (2000), Godfrey-Smith (2000), Aunger (2002), Knudsen (2004), Hodgson and Knudsen (2008a). Hodgson and Knudsen (2004, forthcoming) argue that the concept of the 'interactor' - preferred by Hull (1988) to Dawkins's 'vehicle' - applies to business firms in economic evolution. Following Veblen (1899), Hodgson and Knudsen (2004, forthcoming) argue that habits, routines and customs are replicators in socio-economic evolution.
} 
selection of ideas in human learning and in the development of science. ${ }^{4}$ James (1880, p. 441) opened his essay with the observation of a 'remarkable parallel ... between the facts of social evolution on the one hand, and of zoölogical evolution as expounded by Mr. Darwin on the other.' But his discussion was largely confined to the selection of ideas in the heads of individuals. Subsequently Samuel Alexander (1892) and Benjamin Kidd (1894) wrote on the natural selection of ethical principles.

While several thinkers believed that Darwinian principles apply to social phenomena, they were applied loosely and incompletely. Hence Bagehot's emphasis was on the struggle between nations, not on a process of selection involving additional social units or structures. He did not emphasize institutions as units of selection. Sidney Webb (1889, p. 53) insisted that 'the units selected are not individuals but societies'. But he was also unclear of the mechanisms or criteria of selection, other than to allude to the competitive struggle between nations for access to raw materials and for supremacy in world markets. Kidd (1894, p. 43) wrote of human 'societies' and 'the survivals of the fittest' in the same sentence, but did not clearly establish any notion that social structures were themselves subject to selection processes as well as individuals. Henry Drummond (1894) saw Darwinian evolution in human society, but he did not examine the units of selection and processes of replication in more detail. These writers failed to consider the 'natural selection' of social structures or institutions. When they applied Darwinian selection, it was loosely to collections of individuals. In seeing individuals as units of selection, it was widely accepted that the selected traits might also be conducive to the harmony and the survival of groups or nations. But this did not establish a rigorous concept of selection at the group or higher level.

Accordingly, these early extensions of Darwinian principles to social evolution failed to establish the social units of replication and selections, other than to refer imprecisely to societies or groups. It was not explained why human social evolution involved anything more than the selection of individuals. After all, the selection or fitness advantage of one group over another may simply result from the selection or fitness advantages of the members of the more adapted group. In this case, social fitness amounts to nothing more than a sum of individual fitness. Without a supplementary explanation, such notions of 'social' evolution dissolve simply into the evolution and selection of human individuals.

\footnotetext{
${ }^{4}$ Evolutionary epistemology was later rediscovered and developed by Popper (1972) and Campbell (1974).
} 


\section{Early Recognitions of Social Units of Replication or Selection}

In the 1890s, and independently of each other, two writers first formulated the notion that there were social units of selection, irreducible to individuals, to which Darwinian principles might apply.

In Darwinism and Politics, Ritchie (1889, p. 59) upheld that in human societies 'language and social institutions make it possible to transmit experience quite independently of the continuity of race'. In other words, cultural transmission functioned alongside, and in addition to, what today we describe as genetic inheritance. George Henry Lewes (1879) and Henry Drummond (1894) had previously suggested this idea. Ritchie (1889, p. 59) argued: 'An individual or a nation may do more for mankind by handing on ideas and a great example than by leaving numerous offspring.' In the second edition of this book, Ritchie (1891) added an essay 'Natural selection and the history of institutions' and argued that Darwinian principles of variation, heredity and selection applied to the evolution of social institutions as well as to organisms. Ritchie repeated that language and institutions are social mechanisms through which adaptations and knowledge may be inherited. He wrote of a struggle between 'institutions, languages, ideas' as well as a struggle between individuals. But Ritchie warned that although Darwinian principles applied to social evolution, they must always be used carefully, with meticulous acknowledgement of the differences in the mechanisms involved.

In a later article Ritchie (1896) developed these ideas in more depth. Although he regarded biology as a better source of ideas for the social sciences than physics or chemistry, he repeatedly warned against the casual and uncritical use of biological terms in a social context. Ritchie argued that there was not simply a process of struggle in society between individuals, but also one between different 'social organisms' including the family, social organizations, nations and so on. This second level struggle vastly complicated the processes of social evolution and selection. For instance, as Ritchie pointed out, one individual might simultaneously belong to several social units or institutions. Accordingly, the processes of selection at a social level might conflict with each other, as well as with the natural selection of individuals.

Ritchie noted that natural and social evolution differed in other respects. For instance, selection in the natural world works through the death of the unfit. In contrast, in the social sphere, it is not simply through 'the slow and deadly process of natural selection that the 
various elements in our civilization have been produced, preserved, and diffused.' Ritchie $(1896,168-9)$ argued that in social evolution 'a great many habits are due to imitation and not to instinct, i.e., they are transmitted in the social inheritance of the race, and are not dependent on heredity, in the biological sense'. For Ritchie, this developed capacity to imitate involved a degree of consciousness and reflection. In these circumstances both 'the habit may be changed without the extinction of the race ... customs and institutions may perish without the necessary destruction of the race that practiced them' and 'customs and institutions may be handed on from race to race, and may long survive the race from whom they originated' (ibid., p. 170). The life span of the social units of selection could be entirely non-coextensive with the lives of the human individuals that sustained them.

While carefully acknowledging these important differences, Ritchie still regarded the theory of selection as being applicable to the social domain. Despite detailed differences of evolutionary mechanism, the 'range' of Darwinian theory could be extended from the biological to the social sphere. In a prescient passage, Ritchie (1896, pp. 170-1) wrote:

But in asserting that human society presents many phenomena that cannot be accounted for by natural selection in its purely biological sense, I am not denying the truth of the theory, but rather extending its range. There is going on a 'natural selection' of ideas, customs, institutions, irrespective of the natural selection of individuals and of races.

This quotation contains a path-breaking recognition that Darwinian principles could be applied to social evolution and to non-biological units of replication or selection.

Crucially Ritchie recognized that the units of replication or selection could be social entities such as customs and institutions, rather than individuals alone. This is possibly the first explicit appearance of the idea of a natural selection of customs, institutions or social structures in the English language.

The second scholar to write of institutions as units of selection was Thorstein Veblen. The British zoologist and philosopher Conwy Lloyd Morgan may have helped stimulate Veblen's thinking in this area; circumstantial evidence exists that Veblen came into contact with Morgan in Chicago in 1896 (Dorfman 1934, Hodgson 2004a). In any case, Veblen's idea of 'the natural selection of institutions' dates from this time.

By 1896 Morgan had accepted the arguments of August Weismann (1893) that acquired characters could not be inherited in the biological sphere. Rejecting Lamarck in favor of 
Weismann, Morgan then asked: if human beings had evolved only slightly in genetic terms, then what had evolved in the last millennium or so, when human achievements have been transformed beyond measure? Morgan's (1896, p. 340) answer to the puzzle was as follows:

This is that evolution has been transferred from the organism to the environment. There must be increment somewhere, otherwise evolution is impossible. In social evolution on this view, the increment is by storage in the social environment to which each new generation adapts itself, with no increased native power of adaptation. In the written record, in social traditions, in the manifold inventions which make scientific and industrial progress possible, in the products of art, and the recorded examples of noble lives, we have an environment which is at the same time the product of mental evolution, and affords the condition of the development of each individual mind to-day ... this transference of evolution from the individual to the environment may leave the faculty of the race at a standstill, while the achievements of the race are progressing by leaps and bounds.

Morgan thus established the possibility of social evolution having a substance and pace that was reducible neither to individuals nor their biological attributes. Information and knowledge were more than a passive environment of biotic selection in human evolution, but involved a level of inheritance in their own right. Morgan added to Lewes's account an insistence - in line with the work of Weismann - that human biotic and mental capacities could not evolve so rapidly as to account for the evolution of human civilization.

In a book review of a work by Antonio Labriola, Veblen (1897, p. 390) saw in Labriola's Marxism the doctrine that the 'economic exigencies' of the industrial process 'afford the definitive test of fitness in the adaptation of all human institutions by a process of selective elimination of the economically unfit.' But these were Veblen's words, not Labriola's. Veblen made the additional and substantial theoretical leap of applying the principle of selection to institutions, and not merely to individuals or groups.

For Veblen, the institutional structure of society was not merely 'the environment'. Veblen pointed to institutional elements that were themselves, like organisms, subject to evolutionary processes of selection. Darwinism was interpreted not narrowly in terms of individuals being selected in a fixed environment, but in an environment that is changed in its interaction with those creative individuals. As Veblen (1898, p. 391) put it: 'The economic life history of the individual is a cumulative process of adaptation of means to ends that cumulatively change as 
the process goes on, both the agent and his environment being at any point the outcome of the last process.' Veblen (1898, p. 393) concluded that 'an evolutionary economics must be a theory of a process of cultural growth as determined by the economic interest, a theory of a cumulative sequence of economic institutions stated in terms of the process itself.' This was essentially the core theoretical project of Veblen's The Theory of the Leisure Class. In a key passage, Veblen (1899, p. 188) declared:

The life of man in society, just like the life of other species, is a struggle for existence, and therefore it is a process of selective adaptation. The evolution of social structure has been a process of natural selection of institutions. The progress which has been and is being made in human institutions and in human character may be set down, broadly, to a natural selection of the fittest habits of thought and to a process of enforced adaptation of individuals to an environment which has progressively changed with the growth of community and with the changing institutions under which men have lived. Institutions are not only themselves the result of a selective and adaptive process which shapes the prevailing or dominant types of spiritual attitude and aptitudes; they are at the same time special methods of life and human relations, and are therefore in their turn efficient factors of selection. So that the changing institutions in their turn make for a further selection of individuals endowed with the fittest temperament, and a further adaptation of individual temperament and habits to the changing environment through the formation of new institutions.

It was no accident that Darwin's phrases 'natural selection' and 'struggle for existence' appeared here. Veblen (1899, p. 207) wrote also in the same work of the law of natural selection, as applied to human institutions'. Apparently without of the influence of Ritchie, but with the probable inspiration of Morgan, Veblen became the second writer after the publication of the Origin of Species to apply forcefully Darwin's principle of selection to the evolution of customs and institutions. The decisive implication was that Darwinism could be applied to human society without necessarily reducing explanations of social phenomena entirely to individual psychology or biology. As Veblen (1909, p. 300) wrote:

If ... men universally acted not on the conventional grounds and values afforded by the fabric of institutions, but solely and directly on the grounds and values afforded by the unconventionalised propensities and aptitudes of hereditary human nature, then there would be no institutions and no culture. 
Veblen thus suggested that if socio-economic phenomena were determined exclusively by biological factors, then the concepts of institution and culture would be redundant. Culture and institutions are irreducible to biological factors alone. Veblen thus broke decisively from biological reductionism. Consistent with this interpretation, the concepts of cultural and institutional evolution were developed his Theory of the Leisure Class.

Ritchie and Veblen died in 1903 and 1929 respectively. Few of their followers and contemporaries pursued further the research agenda of applying Darwinian principles to the evolution of social entities and units.

The psychologist James Mark Baldwin was another writer to accept the importance of Darwinian principles in the social sphere. Baldwin (1909, p. 44) saw groups as possible units of selection. In terms similar to those of Morgan, Lewes and others, he saw the 'absorption of the social tradition' as a key mechanism of social evolution (p. 52). Baldwin (p. 55) wrote that 'Darwin struck upon a law of universal application in nature'. Like others, he acknowledged the possibility of a natural selection of ideas as the grounding of an evolutionary epistemology. One of Baldwin's key innovations was to extend the theory of natural selection to the theory of human development and learning (Richards, 1987).

Baldwin considered the basis of social integration and solidarity, and emphasized the importance of self-reflective behaviour at the social level. But although he saw social groups as possible units of selection, he had no developed notion of institutions or social structures. Essentially he applied Darwinism more to the natural rather than the social world, and his contribution to the Darwinian theory of social evolution was less important than that of Ritchie or Veblen.

Another rare extension of Darwinian principles to social evolution is in a work by Albert Galloway Keller (1915), who was a student of William Graham Sumner. Unlike Sumner, Keller (1915, p. 15) enthusiastically applauded the application of Darwinian principles to social evolution. ${ }^{5}$ It was not merely a matter of analogy, but of acknowledging that social evolution was Darwinian in a fundamental sense: 'I find a something in the social field which

\footnotetext{
5 Despite Sumner's contemporary description as a 'Social Darwinist', Keller (1923, p. 137) rightly observed that his teacher 'did not give much attention to the possibility of extending evolution into the societal field.' In fact, Sumner seldom mentioned Darwin or Darwinism, and his association with 'Social Darwinism' is inaccurate and highly misleading (Bannister 1973; Hodgson 2004b).
} 
is variation, whether or not it may be like what is called variation in the organic field; similarly social selection is selection and not merely like it.' Sumner's influence was present, however, in Keller's (1915, p. 41) choice of 'folkways' as the basic units of social evolution: 'The folkways are the simplest and most fundamental phenomena of societal life. They are the germ and matrix of all human institutions.' Keller wrote also of the processes of selection of social mores, and of tradition as the factor of social evolution corresponding to heredity in organic evolution as tradition, kept alive by imitation.

Although Keller's account lacks an adequate philosophical apparatus to sustain multiple levels of selection including units of selection at the social level, it is one of the most advanced tracts on this theme in the period.

But the project to apply Darwinian principles rigorously to social evolution was pushed off the agenda of the social sciences after the First World War (Degler 1991, Hodgson 2004a, 2004b). Phrases such as 'survival of the fittest' had been slogans for racism and nationalism, and many intellectuals believed in eugenics. In reaction, a growing movement within the Anglophone intelligentsia rejected all links between biology and social thought. These was the 'dark age' for evolutionism in the social sciences: 'During this time evolutionism was severely criticized and came to be regarded as an outmoded approach that self-respecting scholars should no longer take seriously ... even the word "evolution" came to be uttered at serious risk to one's intellectual reputation' (Sanderson, 1990, p. 2).

Among the criticisms raised at the time was the view that Darwinian evolution is 'blind' and hence ignores or underestimates human intentionality (e.g. Commons (1924) and Penrose (1952)). This interpretation is mistaken. Darwin himself accepted that humans are intentional, but insisted that the capacity for intentional behaviour had evolved and was foreshadowed in our pre-human ancestors (Darwin 1859, p. 208; 1871, vol. 1, p. 46). Darwin neither denied nor neglected human intentionality, but insisted that it had evolved and was subject to a causal explanation. Another erroneous basis for dismissing Darwinism was that it involved 'natural selection', whereas social evolution involves 'artificial selection' (Commons, 1924, p. 376). However, Darwin did not suggest that 'artificial' and 'natural' selection were mutually exclusive. Instead, examples of the former were used by Darwin to support the idea of the latter.

Furthermore, while Darwinian biology made major breakthroughs in the period from the 1930s to the 1950s, an adequate refinement of general Darwinian concepts such as selection, 
replication and inheritance - in terms that could be applied to socio-economic evolution without forcing it entirely into a biological mould - was lacking. Indeed, adequate and precise generalizations of these Darwinian terms did not appear until the final years of the twentieth century. ${ }^{6}$

In the hostile intellectual environment of the 1930s and 1940s, the theory of Darwinian social evolution lay mostly dormant and undeveloped, until it began to be revived after the Second World War, notably by the diplomat, corporate legal theorist and economist Adolf A. Berle (1950), the archaeologist V. Gordon Childe (1951) and the psychologist Donald T. Campbell (1965). Campbell (1965, p. 24) made the point that the appropriate analogy for social evolution is not biotic evolution, but a more general processes of evolution 'for which organic evolution is but one instance.' This was an idea that Campbell had helped to revive, but was then already a hundred years old.

\section{Conclusion: Looking Forward From the Past}

It is beyond the scope of this paper to review the recent literature that attempts to apply Darwinian principles to social or cultural evolution. But consideration of the earlier literature cited above suggests some questions and issues that remain to be addressed.

First, absent in this early literature were rigorous definitions of the core concepts of a generalized Darwinism, including variation, selection and replication. Mechanisms of selection were typically not discussed in much detail. Furthermore, these earlier writers failed to distinguish between the cohesive entity that is actually being selected (the phenotypes or interactors) and the entities that replicate differentially as a result of selection (the genotypes or replicators). Candidate social interactors might include firms and other cohesive organizations (Hodgson and Knudsen 2004). Candidate social replicators might include customs, routines and 'folkways' (Keller 1915, Nelson and Winter 1982). These issues of conceptual precision definition and exploration remain with us today, although some significant progress has been made in recent years.

Second, a central but unfinished task is to establish the nature of sociality, and social units of replication or selection. Important developments haven been made in the theory of gene-

\footnotetext{
6 See Hull (1988), Godfrey-Smith (2000), Price (1995), Sperber (2000), Hodgson and Knudsen (2008a, forthcoming).
} 
culture coevolution by Robert Boyd and Peter Richerson (1985), William Durham (1991) and others. Their accounts of evolutionary selection include the selection of individuals and the resulting loss of some ideas and the survival of others, or the deliberate choice by individuals of one set of ideas rather than another. While all these developments are of considerable importance, there is little connection with the vast literature in social theory that focuses on social structures and institutions, and their irreducibility to individuals or ideas.

The key question is this: what makes an entity social, rather than merely being a common attribute of a number of individuals? The answer must involve some notion of social structure, with properties that are irreducible to individuals alone (Archer 1995, Kontopoulos 1993, Weissman 2000). However, despite earlier important statements of the 'natural selection of institutions', the concept of social structure has yet to be adequately incorporated in a Darwinian evolutionary framework.

Following Ritchie or Veblen, we need to make progress in establishing social institutions or structures as units of replication or selection. A pressing task is either to follow up these earlier hints in a rigorous way, or to show that such social units of replication or selection are unviable. Recent careful analytical work on group selection is relevant here. This establishes the special conditions under which groups may emerge as units of selection in biological as well as social evolution. ${ }^{7}$ But pointing to groups as possible units of selection is not enough. It has to be shown that groups have emergent properties that are irreducible to the properties of their members. The mechanisms of group cohesion and the constraints on inter-group migration have thus to be explained.

Clearly, human sociality involves more than the anthill or the beehive. In particular, it relies on language and culture, with intersubjective interpretations of intention and meaning (Bogdan, 2000). These complex causal interactions are the basis of emergent social properties. These properties have to be described and analyzed before they play their part in a theory of socio-economic evolution. By contrast, the attributes of sociality cannot be established simply by regarding the human as social by definition, or loosely defining the social simply in terms of human interaction. These looser and broader statements are insufficient to identify social interactors, social replicators and mechanisms of social

\footnotetext{
${ }^{7}$ For good accounts of group selection see Sober (1981), Sober and Wilson (1998), Bergstrom (2002) and Henrich (2004).
} 
replication. To establish the essence of human sociality and place it an evolutionary framework, an intensive and detailed dialogue has to be created between evolutionary and social theory.

These steps, if completed, would consolidate the suggestions of Ritchie (1896), Veblen (1899) and Keller (1915) concerning social units of selection, but with the significant additional benefit of modern developments in social theory, psychology, anthropology and the philosophy of science. This work would connect with a substantial body of literature in organization science and evolutionary economics, which has proposed social replicators such as routines and suggested viable mechanisms of selection (Aldrich 1999, Nelson and Winter 1982). In all, the possibility of a Darwinian and evolutionary social science is now in prospect, after some pioneering authors envisaged it around a century ago.

Perhaps two of the most important lessons are these. To further this project it is important that social scientists appreciate the value of Darwinism. It is also important for natural and behavioural scientists to appreciate social entities, and social levels of evolution and selection, above the level of the gene. 


\section{References}

ALDRICH, H. E. (1999): Organizations Evolving. London: Sage,

ALDRICH, H. E., HODGSON, G. M., HULL, D. L., KNUDSEN, T., MOKYR, J. and VANBERG, V. J. (2008): In defence of generalized Darwinism, Journal of Evolutionary Economics, 18, 577-596.

ALEXANDER, S. (1892): Natural selection in morals, International Journal of Ethics, 2, 409-439.

AUNGER, R. (2002): The Electric Meme: A New Theory of How We Think. New York: Free Press.

ARCHER, M. S. (1995): Realist Social Theory: The Morphogenetic Approach. Cambridge: Cambridge University Press.

BAGEHOT, W. (1872): Physics and Politics, or, Thoughts on the Application of the Principles of 'Natural Selection' and 'Inheritance' to Political Society. London: Henry King.

BALDWIN, J. M. (1909): Darwin and the Humanities. Baltimore: Review Publishing.

BANNISTER, R. C. (1973): 'William Graham Sumner’s social Darwinism: A reconsideration', History of Political Economy, 5, 89-108.

BERGSTROM, T. C. (2002): Evolution of social behavior: individual and group selection', Journal of Economic Perspectives, 16, 67-88.

BERLE, A. A. (1950): Natural Selection of Political Forces. Lawrence, Kansas: University of Kansas Press.

BOGDAN, R. (2000): Minding Minds: Evolving a Reflexive Mind in Interpreting Others. Cambridge, MA: MIT Press.

BOWLER, P. J. (1983): The Eclipse of Darwinism: Anti-Darwinian Evolution Theories in the Decades around 1900. Baltimore: Johns Hopkins University Press.

BOYD, R. and RICHERSON, P. J. (1985): Culture and the Evolutionary Process. Chicago: University of Chicago Press. 
CAMPBELL, D. T. (1965): Variation, selection and retention in sociocultural evolution. In BARRINGER, H. R., BLANKSTEN, G. I. and MACK, R. W. (eds): Social Change in Developing Areas: A Reinterpretation of Evolutionary Theory. Cambridge, MA: Schenkman, pp. 19-49.

CAMPBELL, D. T. (1974): Evolutionary epistemology. In SCHILPP, P. A. (ed.) The Philosophy of Karl Popper (Vol. 14, I \& II). The Library of Living Philosophers. La Salle, Ill: Open Court, pp. 413-463.

CHILDE, V. G. (1951): Social Evolution. London: Watts.

COMMONS, J. R. (1924): Legal Foundations of Capitalism. New York: Macmillan.

CZIKO, G. (1995): Without Miracles: Universal Selection Theory and the Second Darwinian Revolution. Cambridge, MA: MIT Press.

DARWIN, C. R. (1859): On the Origin of Species by Means of Natural Selection, or the Preservation of Favoured Races in the Struggle for Life. London: Murray.

DARWIN, C. R. (1871): The Descent of Man, and Selection in Relation to Sex, 2 vols. London: Murray and New York: Hill.

DAWKINS, R. (1976): The Selfish Gene. Oxford: Oxford University Press.

DAWKINS, R. (1983): Universal Darwinism. In D. S. Bendall (ed.) Evolution from Molecules to Man. Cambridge: Cambridge University Press, pp. 403-425.

DEGLER, C. N. (1991): In Search of Human Nature: The Decline and Revival of Darwinism in American Social Thought. Oxford and New York: Oxford University Press.

DENNETT, D. C. (1995): Darwin's Dangerous Idea: Evolution and the Meanings of Life. London: Allen Lane.

DORFMAN, J. (1934): Thorstein Veblen and His America. New York: Viking Press.

DRUMMOND, H. (1894): The Ascent of Man. London: Hodder and Stoughton.

DURHAM, W. H. (1991): Coevolution: Genes, Culture, and Human Diversity. Stanford: Stanford University Press.

EDELMAN, G. M. (1987): Neural Darwinism: The Theory of Neuronal Group Selection. New York: Basic Books. 
GODFREY-SMITH, P. (2000): The replicator in retrospect. Biology and Philosophy, 15, 403423.

HAYEK, Friedrich A. (1988): The Fatal Conceit: The Errors of Socialism. London: Routledge.

HENRICH, J. (2004): Cultural group selection, coevolutionary processes and large-scale cooperation. Journal of Economic Behavior and Organization, 53, 3-35.

HODGSON, G. M. (2004a): The Evolution of Institutional Economics: Agency, Structure and Darwinism in American Institutionalism. London and New York: Routledge.

HODGSON, G. M. (2004b): Social Darwinism in Anglophone academic journals: a contribution to the history of the term. Journal of Historical Sociology, 14, 428-463.

HODGSON, G. M. (2005): Generalizing Darwinism to social evolution: some early attempts, Journal of Economic Issues, 39, 899-914.

HODGSON, G. M. and KNUDSEN, T. (2004): the firm as an interactor: firms as vehicles for habits and routines', Journal of Evolutionary Economics, 14, 281-307.

HODGSON, G. M. and KNUDSEN, T. (2006a): 'Why we need a generalized Darwinism: and why a generalized Darwinism is not enough', Journal of Economic Behavior and Organization, 61, 1-19.

HODGSON, G. M. and KNUDSEN, T. (2006b): 'Dismantling Lamarckism: Why descriptions of socio-economic evolution as Lamarckian are misleading', Journal of Evolutionary Economics, 16, 343-66.

HODGSON, G. M. and KNUDSEN, T. (2006c): 'The nature and units of social selection', Journal of Evolutionary Economics, 16, 477-89.

HODGSON, G. M. and KNUDSEN, T. (2008a): 'Information, complexity and generative replication', Biology and Philosophy, 43, 47-65.

HODGSON, G. M. and KNUDSEN, T. (2008b): 'In search of general evolutionary principles: why Darwinism is too important to be left to the biologists', Journal of Bioeconomics, 10 , 51-69. 
HODGSON, G. M. and KNUDSEN, T. (forthcoming): Darwin's Conjecture: The Search for General Principles of Social and Economic Evolution. Chicago: University of Chicago Press.

HULL, D. L. (1988): Science as a Process: An Evolutionary Account of the Social and Conceptual Development of Science. Chicago: University of Chicago Press.

HULL, D. L., LANGMAN, R. E., and GLENN, S. S. (2001): A general account of selection: biology, immunology and behaviour. Behavioral and Brain Sciences, 24, 511-573.

JAMES, W. (1880): Great men, great thoughts, and the environment. Atlantic Monthly, 46, 441-459.

KELLER, A. G. (1915): Societal evolution: a study of the evolutionary basis of the science of society. New York: Macmillan.

KELLER, A. G. (1923): Societal evolution. In Baitsell, G. A. (ed.) The Evolution of Man. New Haven: Yale University Press, pp. 126-151.

KIDD, B. (1894): Social evolution. London and New York: Macmillan.

KNUDSEN, T. (2004): General selection theory and economic evolution: the Price equation and the replicator/interactor distinction. Journal of Economic Methodology, 11, 147-173.

KONTOPOULOS, K. M. (1993): The Logics of Social Structure. Cambridge: Cambridge University Press.

LEWES, G. H. (1879): Problems of Life and Mind: Third Series, vol. 1. London: Trübner.

LEWONTIN, R. C. (1970): The units of selection. Annual Review of Ecology and Systematics, 1, 1-18.

MORGAN, C. L. (1896): Habit and Instinct. London and New York: Edward Arnold.

NELSON, R. R. and Winter, S. G. (1982): An Evolutionary Theory of Economic Change. Cambridge, MA: Harvard University Press.

PENROSE, E. T. (1952): Biological analogies in the theory of the firm. American Economic Review, 42, 804-819.

PLOTKIN, H. C. (1994): Darwin Machines and the Nature of Knowledge: Concerning Adaptations, Instinct and the Evolution of Intelligence. Harmondsworth: Penguin. 
POPPER, K. R. (1972): Objective Knowledge: An Evolutionary Approach. Oxford: Oxford University Press.

PRICE, G. R. (1995): The nature of selection. Journal of Theoretical Biology, 175, 389-396.

RICHARDS, R. J. (1987): Darwin and the Emergence of Evolutionary Theories of Mind and Behavior. Chicago: University of Chicago Press.

SANDERSON, S. K. (1990): Social Evolutionism: A Critical History. Oxford: Basil Blackwell.

SOBER, E. (1981): Holism, individualism, and the units of selection. In ASQUITH, P. D. and GIERE, R. N. (eds) Philosophy of Science Association 1980, Vol. 2. East Lansing, MI: Philosophy of Science Association, 93-121.

SOBER, E. and WILSON, D. S. (1998): Unto Others: The Evolution and Psychology of Unselfish Behavior. Cambridge, MA: Harvard University Press.

SPERBER, D. (2000): An objection to the memetic approach to culture. In Aunger, R. (ed.) Darwinizing Culture: The Status of Memetics as a Science. Oxford and New York: Oxford University Press, pp. 162-73.

STERELNY, K. SMITH, K. C. and DICKISON, M. (1996): The extended replicator. Biology and Philosophy, 11, 377-403.

VEBLEN, T. B. (1897): Review of Essais sur la conception matérialiste de l'histoire by Antonio Labriola, Journal of Political Economy, 5, 390-391.

VEBLEN, T. B. (1898): Why is economics not an evolutionary science? Quarterly Journal of Economics, 12, 373-397.

VEBLEN, T. B. (1899): The Theory of the Leisure Class: An Economic Study in the Evolution of Institutions. New York: Macmillan.

VEBLEN, T. B. (1909): Fisher's rate of interest. Political Science Quarterly, 24, 296-303.

WEBB, S. J. (1889): 'The historic basis of socialism. In Shaw, G. B. (ed.) Fabian Essays in Socialism. London: Fabian Society, pp. 33-61.

WEISMANN, A. (1893): The Germ-Plasm: A Theory of Heredity. London and New York: Walter Scott and Scribner's.

WEISSMAN, D. (2000): A Social Ontology. New Haven, CT: Yale University Press. 